\title{
Professor Handspring's Lecture Notes on Pound's Cantos
}

Edited by J. Roger Dane, Ph.D., Litt.D.

AS WE ADDRESS OURSELVES to Pound's great epic, I must warn you that a too close study of the text may, as the Surgeon General says, be hazardous to your health. To coin a trope, let us imagine that Ernest Hemingway set out to stalk a huge rhinoceros in a boggy waterhole on the Serengetti Plain with a B-B gun. But that figure is too physical. The peril to the brain is far more grave - and far more likely. Even now, five years after they tackled the Cantos, two of my students are still confined in a funny farm, where, day after day, under the benevolent eye of Dr. Merrill, they contentedly question their ouija boards about some of the more obscure of Pound's referents.

Before the advent of the computer, the problem of taxonomy in Pound's allusions, illusions, delusions and mnemonic iterations was thought to be insoluble. But there is little that the 256-K chip cannot handle. Two years ago I was thrilled to hear from Universitaet Donnerwetter in Lower Thuringia (a region with which, I must confess, I have an ancestral connection) that the distinguished computer scientist Professor Alois Finkbein had undertaken a comprehensive enumeration of all the signifieds in the Cantos. But now there has come distressing news from the Federal Republic. In certain areas of the poem, Prof. Finkbein's apparat has begun to flash a red message to him: Kein mehr Lagerung! So I fear that the New Learning may have let us down, Hoffsteter has failed us. It looks as though we Poundians are back at Square 1.

Not from the Deconstructionist, but from the old-fashioned psychological basis, what is our dilemma? Or what was Pound's problem? Why was it necessary for him so to proliferate the disjunctivitis of his ideogrammatic method of composition? Why were the "personae" of Personae multiplied a thousand fold in the Cantos? Why the Klangeffekt which Fuschelhaffer of Kuesnacht first noted in the Greek tags of Mauberley swell from Seven Tailors to Seven Hundred Tailors? Let us try to visualize the problem. You will surely remember in that great classic of the American film Citizen Kane the scene in the cellars of San Simeon in which the camera must pan 
out endlessly to take in all the unopened crates of art works which the great collector had assembled. Should we see it so with the author of the Cantos? Everything that he ever heard, studied, saw or remembered seems to have been permanently etched on the photographic plates of his mind. Dove sta tutta la memoria de tout le tribu. One day I was talking about this with that acerb old bear Kenneth Rexroth. "God, Hi," he said, "what can you see in that dreadful man? Not only is he a Jew-burner but he is totally anal-retentive."

"How can you say that," I rejoindered, "he's not at all like Hearst. Everything he absorbs he gives back. It's total evacuation."

"Oh shit, Hi," said Rexroth, "you know better."

We are in a quandary. How to excavate so much and what to do with the material we excavate. But the operation has great rewards. We can become happily obsessed with it. It can become a way of life-a very full life. This you will discover when you go to your first Pound Conference. And, of course, to attend Pound Conferences must surely be the highest goal of any ambitious young academic. All the great Poundian brains flock to Pound Conferences, which are held in such glamorous places as Odorono, Perigueux, Bellagio, Urbino and Little Piddle-on-Trenthide. I realize, however, that you may be extremely timid, even terrified about your first Conference. What if Dr. Kenner or Prof. Perloff were to ask you a testing question? I think I can help you with that anxiety. Having been to several Pound Conferences, I have picked up a bit of the lingo. I can give you certain passwords. In a squinch, use one of these passwords, and the Big Brains will recognize you as one among them and extend the glad hand of fraternal welcome.

For a safe starter we have Nekuia, the descent into the underworld, as we find it in Canto I, where Pound/Odysseus goes down to consult with Parson Eliot's pal, Tiresias. The chthonian gambit, or Eva Hesse's opening. Naturally no eminent Poundian would refer to the first canto as Canto I. It's the Nekuia Canto. So you might ask Ron Bush how he reads line 62 of the Nekuia. "Rather tricky, don't you think, that bit about the 'bloody bever'? It's 'beaver,' of course, but then what? I understand that Baciagalupo is now reading the secondary as a corruption of 'beauvoir.' What do you think?" But Bush might just say, "You didn't read my book very carefully, did you?" Not so good. Perhaps better to ask him to run 
the "ell-square pitkin" (line 21) against Williams' "The descent beckons " That would put him on the defensive if he didn't happen to know that the good doctor of Rutherford always used a "Suredig" spade to turn the loam in his rose garden.

Other good in-words at Pound Conferences are Plumetis, the man of many counsels, Homer's epithet for Odysseus (for whom Pound often mistook himself); Paideuma, "a people's whole congeries of patterned energies" (Kenner ex Herr Geheimrat Frobenius); and Periplum, the circumnavigation of the Mare Azzuro (also known as the winedark sea). English Poundians seem to have become rather fond of the Periplum lately, nostalgia perhaps for when they ruled the waves. Use that with them. Finally, if you paint yourself in a corner, and if there is a lake or ocean in view, or, in the worst case, a toilet flushing, just cup your hand to your ear and murmur poluphloisboio thallases, the roaring of the surf upon the strand. . . 